\title{
Increased tissue concentrations of 5-hydroxytryptamine in the duodenal mucosa of patients with coeliac disease
}

\author{
D. N. CHALlaCOMBE, P. D. DAWKINS, AND P. BAKER \\ From the Children's Research Unit and Department of Pathology, Taunton and Somerset Hospital, \\ Taunton, Somerset
}

SUMMARY Tissue concentrations of 5-HT have been measured in the duodenal mucosa of adults and children with coeliac disease and were found to be significantly higher than those from a control group. This finding may be associated with hyperactivity or hyperplasia of enterochromaffin (EC) cells in the duodenum of patients with coeliac disease and could also be directly related to described abnormalities of 5-HT metabolism in this disease.

Increased urinary excretion of 5-hydroxyindoleacetic acid (5-HIAA), a metabolite of 5-hydroxytryptamine (5-HT), has been reported in both adults and children with untreated coeliac disease (Haverback and Davidson, 1958; Haverback et al., 1960; Pimparker et al., 1961; Scriver, 1961; Sleisenger, 1961; Benson et al., 1964; Kowlessar et al., 1964; Challacombe et al., 1972). Clinical recovery after the introduction of a gluten-free diet was accompanied by a fall in urinary 5-HIAA (Sleisenger, 1961; Benson et al., 1964; Kowlessar et al., 1964; Challacombe et al., 1972). Raised blood levels of 5-HT in coeliac disease (Pimparker et al., 1961; Warner and Cohen, 1962) also return to normal after gluten withdrawal from the diet. 5-HT is synthesised in the small intestine by enterochromaffin (EC) cells, and hyperplasia of these cells has been reported in patients with coeliac disease (Challacombe and Robertson, 1976). In the present investigation, tissue levels of 5-HT were estimated in the duodenal mucosa of adults and children with coeliac disease and the results compared with a group of controls.

\section{Methods}

SUBJECTS

\section{Coeliac disease}

Peroral biopsies were performed on four adults and seven children with untreated coeliac disease. Light microscopic examination of the duodenal mucosa showed subtotal villous atrophy and increased

Received for publication 23 March 1977 cellular infiltration of the lamina propria. Introduction of a gluten-free diet to these patients resulted in clinical recovery.

\section{Controls}

Four adults and six children underwent peroral duodenal biopsy to investigate suspected malabsorption. Morphology of the duodenal mucosa on light microscopy in all patients was within normal limits.

\section{Gluten challenge}

Three children with a clinical history suggestive of coeliac disease were subjected to biopsy and initial examination of the duodenal mucosa by light microscopy showed only minor villous abnormalities. After 10 days on an oral challenge of $10 \mathrm{~g}$ gluten powder (Energen Foods, Ltd) three times a day, a second biopsy from the same part of the duodenum showed more severe histopathological changes. These were characterised by increased cellular infiltration of the lamina propria and partial villous atrophy. Introduction of a gluten-free diet to these patients resulted in clinical recovery.

\section{TECHNIQUES}

\section{Small intestinal biopsy}

Tissue from a standard site between the third and fourth part of the duodenum was obtained by peroral biopsy under fluoroscopic control using a Watson adult intestinal biopsy capsule. After dividing the specimen, one segment was used for histological examination while the other was weighed on a five- 
place micro-balance. This tissue was wrapped in metal foil to prevent drying, placed in a plastic tube, and stored in liquid nitrogen until analysed.

\section{Measurement of tissue 5-hydroxytryptamine}

5-HT was extracted from duodenal tissue by the method of Snyder et al. (1965) as modified by Small and Holton (1970), and was determined fluorometrically by its reaction with o-phthalaldehyde (Curzon and Green, 1970).

Duodenal biopsy tissue was homogenised in a small glass homogeniser with $2.5 \mathrm{ml}$ ice cold $0.4 \mathrm{M}$ perchloric acid, to which had been added $0.05 \mathrm{ml}$ of a solution containing $0.05 \mathrm{M}$ disodium EDTA, $0 \cdot 17 \mathrm{M}$ ascorbic acid, and $0 \cdot 15 \mathrm{M}$ sodium chloride. The homogenate was centrifuged at $2000 \mathrm{rpm}$ for 10 minutes and to $2 \mathrm{ml}$ of the supernatant was added $0.5 \mathrm{ml} 0.5 \mathrm{M}$ sodium borate buffer ( $\mathrm{pH} 10), 0.5 \mathrm{ml}$ $1.5 \mathrm{M}$ sodium hydroxide, and $1 \mathrm{~g}$ solid sodium chloride. The solution was mixed well after each addition, and especially after adding sodium chloride to ensure complete saturation. Eight millilitres of $\mathrm{n}$-butanol was then added and the mixture shaken for $\mathbf{1 0}$ minutes at room temperature. After allowing the two phases to separate, as much as possible of the lower phase was removed. One millilitre of $0.1 \mathrm{M}$ sodium borate buffer ( $\mathrm{pH} 10)$, which had previously been saturated with sodium chloride, was then added and the mixture shaken for three minutes. The lower layer was again removed and the upper layer cleared by a brief period of centrifugation. A $5 \mathrm{ml}$ aliquot of the upper n-butanol layer was then shaken for five minutes with $10 \mathrm{ml} \mathrm{n}$-heptane and $1 \mathrm{ml} 8 \mathrm{mM}$ cysteine in $0.1 \mathrm{M}$ hydrochloric acid. After removing most of the upper layer, two $0.3 \mathrm{ml}$ aliquots of the lower layer were added to two test tubes. To the first tube, the blank, was added $1.8 \mathrm{ml} 10 \mathrm{M}$ hydrochloric acid and to the second tube, the test, was added $1.8 \mathrm{ml} 0.3 \mathrm{mM}$ o-phthalaldehyde in $10 \mathrm{M}$ hydrochloric acid. After mixing, both tubes were heated in a boiling water bath for 15 minutes. The tubes were cooled in cold water and fluorescence measured in a Perkin-Elmer MPF-3 fluorescence spectrophotometer at activation and emission wavelengths of $360 \mathrm{~nm}$ and $470 \mathrm{~nm}$ respectively. A stock standard solution of serotonin creatinine sulphate ( $23 \mathrm{mg}$ in $100 \mathrm{ml}$ water) was diluted 1 in 100 with $8 \mathrm{mM}$ cysteine in $0 \cdot 1 \mathrm{M}$ hydrochloric acid. This solution was further diluted 1 in 5 with water just before use. $0.5 \mathrm{ml}$ aliquots of this working standard $(200 \mathrm{ng} / \mathrm{ml})$ and $0.5 \mathrm{ml}$ water were mixed with $2.5 \mathrm{ml}$ ice-cold $0.4 \mathrm{M}$ perchloric acid, and $2 \mathrm{ml}$ of these solutions were taken through the entire extraction and assay, as standard and blank. Two reference standards $(0.3 \mathrm{ml}$ of the $200 \mathrm{ng} / \mathrm{ml}$ working standard) and a reference blank $(0.3 \mathrm{ml}$ of $8 \mathrm{mM}$ cysteine in
$0 \cdot 1 \mathrm{M}$ hydrochloric acid), were set up for the final assay procedure to calculate recovery of the extracted standard. During the initial development of the method is was found that after reacting the final tissue extracts with o-phthalaldehyde, the absorption and emission spectra produced were similar to those produced by reacting o-phthalaldehyde with authentic 5-hydroxytryptamine. The insoluble material remaining in the homogeniser was transferred with three separate $3 \mathrm{ml}$ portions of $0.5 \mathrm{M}$ perchloric acid, to the centrifuge tube containing the bulk of the acid-insoluble tissue homogenate. The contents of the tube were mixed well and centrifuged. The supernatant was removed and the tube drained. The residue was mixed with $1 \mathrm{ml} 0.3 \mathrm{M}$ sodium hydroxide and incubated at $37^{\circ} \mathrm{C}$ for one hour. After re-mixing on a vortex mixer, the contents of the tube were centrifuged and $0.2 \mathrm{ml}$ of the clear supernatant was transferred to a clean tube to await protein estimation (Lowry et al., 1951). Tissue concentrations of 5-HT were expressed per gram of tissue weight and per gram of tissue protein.

\section{Results}

Tissue concentrations of 5-HT in patients with coeliac disease and in controls are shown in Table 1. Results from the two groups were compared statistically using Student's $t$ test. Wet weight of duodenal tissue $(\mathrm{mg})$ and protein content $(\mathrm{mg} / \mathrm{g}$ tissue) were not significantly different in the two groups of patients. $(P>0 \cdot 3)$. Tissue concentrations of $5-\mathrm{HT}$ related either to tissue protein $(\mu \mathrm{g} / \mathrm{g}$ tissue protein) or to wet weight of tissue $(\mu \mathrm{g} / \mathrm{g}$ of tissue) were significantly higher in patients with coeliac disease than in the controls $(\mathrm{P}<0.001)$. There was no significant difference between tissue 5-HT concentrations in the adults and children in either the controls $(P>0.7)$ or in patients with coeliac disease (P > 0.7). Results from three children who were challenged with gluten are shown in Table 2. Tissue concentrations of 5-HT in the pre-challenge biopsies were not significantly different from the controls (P > 0.7). Post-challenge 5-HT concentrations in each patient were greater than pre-challenge values, both in relation to tissue weight and to tissue protein. Although mean 5-HT concentrations were greater in the post-challenge biopsies than in the controls, levels did not attain the values found in patients with coeliac disease who had unequivocal histopathological changes in their duodenal biopsies.

\section{Discussion}

5-HT is synthesised from dietary tryptophan by enterochromaffin (EC) cells, situated mainly between 
Table 1 Tissue concentration of 5-HT

\begin{tabular}{|c|c|c|c|c|c|}
\hline Patients & Age & $\begin{array}{l}\text { Tissue weight } \\
\text { (mg) }\end{array}$ & $\begin{array}{l}\text { Tissue protein } \\
\text { (mg/g tissue) }\end{array}$ & $\begin{array}{l}\text { 5-HT/tissue weight } \\
(\mu \mathrm{g} / \mathrm{g})\end{array}$ & $\begin{array}{l}\text { 5-HT/tissue protein } \\
(\mu g / g)\end{array}$ \\
\hline \multicolumn{6}{|l|}{ Controls } \\
\hline 1 & $3 \mathrm{~m}$ & $4 \cdot 5$ & 122 & 6.9 & 57 \\
\hline 2 & $3 \mathrm{~m}$ & 2.6 & 102 & 6.5 & 63 \\
\hline 3 & 1 yr $6 \mathrm{~m}$ & $8 \cdot 0$ & 72 & $4 \cdot 9$ & 68 \\
\hline 4 & $1 \mathrm{yr} 8 \mathrm{~m}$ & $9 \cdot 0$ & 71 & $2 \cdot 6$ & 37 \\
\hline 5 & 1 yr $9 \mathrm{~m}$ & $5 \cdot 2$ & 75 & $5 \cdot 4$ & 72 \\
\hline 7 & Adult & $12 \cdot 3$ & 60 & 4.6 & 77 \\
\hline 8 & Adult & $14 \cdot 0$ & 39 & 1.6 & 41 \\
\hline 9 & Adult & 16.0 & 49 & $1 \cdot 1$ & 23 \\
\hline 10 & Adult & $19 \cdot 8$ & 68 & $4 \cdot 8$ & 70 \\
\hline Mean & & $10 \cdot 2$ & $73 \cdot 5$ & $4 \cdot 2$ & $55 \cdot 3$ \\
\hline SD & & $5 \cdot 4$ & $24 \cdot 0$ & $2 \cdot 0$ & $17 \cdot 9$ \\
\hline 1 & $5 \mathrm{~m}$ & $7 \cdot 0$ & 52 & $8 \cdot 2$ & 158 \\
\hline 2 & $6 \mathrm{~m}$ & 13.0 & 83 & 8.9 & 107 \\
\hline 3 & $9 \mathrm{~m}$ & $15 \cdot 8$ & 79 & $19 \cdot 6$ & 248 \\
\hline 4 & $9 \mathrm{~m}$ & 8.6 & 83 & $9 \cdot 7$ & 117 \\
\hline 5 & 1 yr $2 \mathrm{~m}$ & $27 \cdot 8$ & 84 & $8 \cdot 8$ & 105 \\
\hline 6 & 3 yr $9 \mathrm{~m}$ & $8 \cdot 3$ & 77 & $10 \cdot 0$ & 130 \\
\hline 7 & 5 yr $9 \mathrm{~m}$ & $1 \cdot 6$ & 138 & $17 \cdot 5$ & 127 \\
\hline 8 & Adult & $13 \cdot 2$ & 53 & $7 \cdot 2$ & 137 \\
\hline 9 & Adult & $19 \cdot 0$ & 74 & $10 \cdot 4$ & 141 \\
\hline 10 & Adult & $12 \cdot 3$ & 55 & $8 \cdot 3$ & 152 \\
\hline 11 & Adult & $12 \cdot 7$ & 63 & $10 \cdot 6$ & 168 \\
\hline Mean & & $12 \cdot 7$ & $76 \cdot 5$ & $10 \cdot 8$ & $144 \cdot 5$ \\
\hline SD & & 6.9 & 23.9 & $4 \cdot 0$ & $39 \cdot 8$ \\
\hline $\mathbf{P}$ & & $>0.3$ & $>0.7$ & $<0.001$ & $<0.001$ \\
\hline
\end{tabular}

Table 2 Gluten challenge

\begin{tabular}{|c|c|c|c|c|c|c|c|c|c|}
\hline \multirow[t]{2}{*}{ Patients } & \multirow[t]{2}{*}{$\begin{array}{l}\text { Age } \\
(m)\end{array}$} & \multicolumn{2}{|c|}{$\begin{array}{l}\text { Tissue weight } \\
\text { (mg) }\end{array}$} & \multicolumn{2}{|c|}{$\begin{array}{l}\text { Tissue protein } \\
\text { (mg/g tissue) }\end{array}$} & \multicolumn{2}{|c|}{$\begin{array}{l}\text { 5-HT/tissue weight } \\
(\mu \mathrm{g} / \mathrm{g})\end{array}$} & \multicolumn{2}{|c|}{$\begin{array}{l}5-H T / \text { tissue protein } \\
(\mu \mathrm{g} / \mathrm{g})\end{array}$} \\
\hline & & Pre-chall. & Post chall. & Pre-chall. & Post chall. & Pre-chall. & Post chall. & Pre-chall. & Post chall. \\
\hline 1 & 15 & $8 \cdot 8$ & $12 \cdot 7$ & 99 & 98 & $7 \cdot 4$ & $9 \cdot 2$ & 75 & 93 \\
\hline 2 & 20 & $9 \cdot 7$ & $14 \cdot 4$ & 89 & 88 & $4 \cdot 4$ & $5 \cdot 7$ & 49 & 65 \\
\hline 3 & 20 & $11 \cdot 0$ & $10 \cdot 0$ & 89 & 104 & $2 \cdot 4$ & 7.0 & 27 & 67 \\
\hline Mean & & $9 \cdot 8$ & $12 \cdot 4$ & $92 \cdot 3$ & $96 \cdot 7$ & $4 \cdot 7$ & $7 \cdot 3$ & $50 \cdot 3$ & $75 \cdot 0$ \\
\hline SD & & $1 \cdot 1$ & $2 \cdot 2$ & 5.8 & $8 \cdot 1$ & 2.5 & 1.8 & $24 \cdot 0$ & $15 \cdot 6$ \\
\hline
\end{tabular}

epithelial cells in the crypts of the small intestine. Increased numbers of EC cells have been reported in the duodenal mucosa of children with coeliac disease (Challacombe and Robertson, 1976). In the present study increased tissue concentrations of 5-HT were found in the duodenal mucosa of adults and children with coeliac disease. In three children with coeliac disease who initially had only minor histological abnormalities in the duodenal mucosa, increased tissue levels of 5-HT were found after a 10-day gluten challenge. Further studies will be necessary to determine whether raised tissue levels of 5-HT are due to hyperplasia or hyperactivity of EC cells, or to both. 5-HT is metabolised by the enzyme monoamine oxidase in the tissues to 5-hydroxy- indolylacetaldehyde, which is further oxidised and excreted in the urine as 5-HIAA. Raised levels of 5-HT in the blood (Pimparker et al., 1961; Warner and Cohen, 1962) and 5-HIAA in the urine (Haverback and Davidson, 1958; Haverback et al., 1960; Pimparker et al., 1961; Scriver, 1961; Sleisenger, 1961 ; Benson et al., 1964; Kowlessar et al., 1964; Challacombe et al., 1972; Challacombe et al., 1975) have been reported in patients with untreated coeliac disease. Clinical recovery after the introduction of a gluten-free diet was accompanied by a fall in blood 5-HT (Pimparker et al., 1961) and urinary 5-HIAA (Sleisenger, 1961; Benson et al., 1964; Kowlessar et al., 1964; Challacombe et al., 1972). The metabolic pathway leading to the 
production of 5-HIAA has been studied in adults with coeliac disease using L-tryptophan loading tests (Kowlessar et al., 1964). Significantly increased excretion of 5-HIAA was found in patients with coeliac disease compared with controls, and an augmented shunt of the 5-HT to 5-HIAA pathway in untreated coeliac disease was proposed. Raised urinary excretion of 5-HIAA in coeliac disease could therefore result from increased synthesis of 5-HT in the small intestinal mucosa, with increased release of this amine into the circulation and subsequent breakdown to 5-HIAA. Increased tissue monoamine oxidase activity in the body may also contribute to raised urinary levels of 5-HIAA in coeliac disease. Low levels of this enzyme were found in the duodenal mucosa of children with coeliac disease but platelet concentrations were within the normal range (Challacombe et al., 1971). The intestinal enzyme defect is probably a consequence of local tissue damage. Although monoamine oxidase activity in other tissues has not been estimated, these findings do not suggest that increased enzyme activity is primarily responsible for the increased urinary excretion of 5-HIAA.

Increased duodenal tissue levels of 5-HT may be a non-specific response of the small intestine in susceptible individuals, to many toxic dietary factors, including dietary gluten. An association with villous flattening in other gastrointestinal disorders has not yet been excluded. However, previous studies of urinary 5-HIAA excretion in children suggest that raised excretion may be a specific manifestation of coeliac disease (Challacombe et al., 1972).

Small doses of $5-\mathrm{HT}(10 \mu \mathrm{g} / \mathrm{kg})$ injected into rat peritoneum have been reported to cause an acceleration of crypt cell proliferation and shortening of cell cycle time in the jejunal mucosa when compared with control animals (Tutton, 1974). Conversely, partial 5-HT depletion after injection of 6-fluorotryptophan (a tryptophan hydroxylase inhibitor, which depletes 5-HT stores in the small intestine) retards crypt-cell cycle time (Tutton, 1974). Shortening of cell-cycle time and an expanded proliferative compartment have also been reported in cell kinetic studies on the duodenal mucosa of adults with coeliac disease (Trier and Browning, 1970; Wright et al., 1973, a, b). Altered cell kinetics in rats in response to 5-HT may be a species related phenomenon and inappropriate to man. If, however, a similar response to 5-HT was also present in man, increased local release of 5-HT in the small intestinal mucosa might be related to the histopathological changes found in coeliac disease. Treatment of coeliac disease by the use of pharmacological agents which antagonise the action of 5-HT or inhibit its release from EC cells could then be considered.
We are grateful for the encouragement of Dr J. Harkness and to Dr M. Barry, Dr M. Ellwood, and Dr D. Isaac for allowing us to study their patients. We also gratefully acknowledge the help given by the sisters and staff of the Paediatric Unit. This study was supported by the Research Committee of the South Western Regional Health Authority.

\section{References}

Benson, G. D., Kowlessar, O. D., and Sleisenger, M. H. (1964). Adult coeliac disease with emphasis upon response to the gluten-free diet. Medicine (Balt.), 43, 1-40.

Challacombe, D. N., Brown, G. A., Black, S. C., and Storrie, M. H. (1972). Increased excretion of 5-hydroxyindoleacetic acid in urine of children with untreated coeliac disease. Archives of Disease in Childhood, 47, 442-445.

Challacombe, D. N., Goodall, M., Gaze, H., and Brown, G. A. (1975). Urinary 5-hydroxyindoleacetic acid in 8-hour collections as an aid in diagnosis of coeliac disease. Archives of Disease in Childhood, 50, 779-781.

Challacombe, D. N., and Robertson, K. (1976). Enterochromaffin cells in the duodenal mucosa of children with coeliac disease. Gut, 18, 373-376.

Challacombe, D. N., Sandler, M., and Southgate, J. (1971). Decreased duodenal monoamine oxidase activity in coeliac disease. Archives of Disease in Childhood, 46, 213-215.

Curzon, G., and Green, A. R. (1970). Rapid method for the determination of 5-hydroxytryptamine and 5-hydroxyindoleacetic acid in small regions of rat brain. British Journal of Pharmacology, 39, 653-655.

Haverback, B. J., and Davidson, J. D. (1958). Serotonin and the gastrointestinal tract. Gastroenterology, 35, 570-577.

Haverback, B. J., Dyce, B., and Thomas, H. V. (1960). Indole metabolism in the malabsorption syndrome. New England Journal of Medicine, 262, 754-757.

Kowlessar, O. D., Haeffner, L. J., and Benson, G. D. (1964). Abnormal tryptophan metabolism in patients with adult coeliac disease, with evidence for deficiency of Vitamin B6. Journal of Clinical Investigation, 43, 894-903.

Lowry, O. H., Rosebrough, N. J., Farr, R. J., and Randall, R. J. (1951). Protein measurement with the Folin phenol reagent. Journal of Biological Chemistry, 193, 265-275.

Pimparker, B. D., Senesky, D., and Kalser, M. H. (1961). Blood serotonin in nontropical sprue. Gastroenterology, 40, 504-506.

Scriver, C. R. (1961). Abnormalities of tryptophan metabolism in a patient with malabsorption syndrome. Journal of Laboratory and Clinical Medicine, 58, 908-919.

Sleisenger, M. H. (1961). Clinical and metabolic studies in nontropical sprue. New England Journal of Medicine, 265, 49-56.

Small, N. A., and Holton, J. B. (1970). Determination of platelet serotonin by a fluorometric method. Clinica Chemica Acta, 27, 171-175.

Snyder, S. H., Axelrod, J., and Zweig, M. (1965). A sensitive and specific fluorescence assay for tissue serotonin. Biochemical Pharmacology, 14, 831-835.

Trier, J. S., and Browning, T. H. (1970). Epithelial-cell renewal in cultured duodenal biopsies in celiac sprue. New England Journal of Medicine, 283, 1245-1250.

Tutton, P. J. M. (1974). The influence of serotonin on crypt cell proliferation in the jejunum of rat. Virchows Archiv: Abteilung B: Zellpathologie (Berlin), 16, 79-87.

Warner, R. R. P., and Cohen, N. (1962). Blood serotonin in malabsorption states. American Journal of Digestive Diseases, 7, 553-556. 
Wright, N., Watson, A., Morley, A., Appleton, D., and Marks, J. (1973a). Cell kinetics in flat (avillous) mucosa of the human small intestine. Gut, 14, 701-710.

Wright, N., Watson, A., Morley, A., Appleton, D., Marks,
J., and Douglas, A. (1973b). The cell cycle time in the flat (avillous) mucosa of the human small intestine. Gut, 14, 603-606.

\section{The October 1977 Issue}

\section{THE OCTOBER 1977 ISSUE CONTAINS THE FOLLOWING PAPERS}

Correlation of variations in intraluminal pressure and potential differences in the perfused colon J. G. POSTAIRE, J. GERARD, G. DEVROEDE, AND N. VAN HOUTTE

Immunohistochemistry of carcinoembryonic antigen: characterisation of cross-reactions with other glycoproteins P. ISAACSON AND MARY A. JUDD

Carcinoembryonic antigen (CEA) in the normal human small intestine: a light and electron microscopic study P. ISAACSON AND MARY A. JUDD

Use of an elemental diet (Vivonex) in the management of bile acid-induced diarrhoea L. M. NELSON, H. A. CARMICHAEL, R. I. RUSSELL, AND S. T. ATHERTON

Stagnant loop syndrome in patients with continent ileostomy (intra-abdominal ileal reservoir) $\mathrm{H}$. SCHJøNSBY, J. F. HALVORSEN, T. HOFSTAD, AND N. HOVDENAK

Myopathy in Whipple's disease M. SWASH, M. S. SCHWARTZ, M. J. VANDENBURG, AND D. J. POLLOCK

Effects of long chain fatty acids on solute absorption: perfusion studies in the human jejunum $H$. V. AMMON, P. J. THOMAS, AND S. F. PHILLIPS
Jejunal villous atrophy and granulomatous inflammation responding to a gluten-free diet A. BJøRNEKLETT, O. FAUSA, S. B. REFSUM, H. TORSVIK, AND H. SIGSTAD

Gastric epithelial cell turnover, mucus production, and healing of gastric ulcers with carbenoxolone W. DOMSCHKE, S. DOMSCHKE, J. HAGEL, L. DEMLING, AND D. N. CROFT

Effect of histamine receptor antagonists on bile damage to the gastric mucosa of canine Heidenhain pouches W. D. W. REES, J. RHODES, M. H. WHEELER, E. M. MEEK, B. WILLIAMS, AND R. G. NEWCOMBE

Maximum acid output to graded doses of pentagastrin and its relation to parietal cell mass in Chinese patients with duodenal ulcer F. C. Y. CHENG, S. K. LAM, AND G. B. ONG

Effect of cigarette smoking on the lower oesophageal sphincter D. K. CHATTOPADHYAY, M. G. GREANEY, AND T. T. IRVIN

Electron probe microanalysis in the study of gallstones J. M. BEEN, P. M. BILLS, AND D. LEWIS

Progress report Mechanism of hypogonadism in cirrhotic males J. R. B. GREEN

Notes and activities

Books

Copies are still available and may be obtained from the PUBLISHING MANAGER, BRITISH MEDICAL ASSOCIATION, TAVISTOCK SQUARE, LONDON WClH 9JR, price $£ 2 \cdot 75$, including postage 